\title{
PENGARUH PERMAINAN TARGET TERHADAP AKURASI SHOOTING PADA PERMAINAN FUTSAL DALAM EKSTRAKURIKULER SMAN 2 KOTA SUKABUMI
}

\author{
Okki Rahmattuwlloh Suryadi ${ }^{1}$, Firman Maulana ${ }^{2}$, Harmi Saputri ${ }^{3}$ \\ ${ }^{1}$ Universitas Muhammadiyah Sukabumi ${ }^{1,2,3}$ \\ okkirahmatt@gmail.com ${ }^{1}$, Fimanmaulana@ummi.ac.id ${ }^{2}$, harmisaputri87@ummi.ac.id ${ }^{3}$
}

\begin{abstract}
ABSTRAK
Dalam peneitian ini bertujuan untuk mengetahui adanya pengaruh permainan taget terhadap akurasi shooting pada permianan futsal di ektrakurikuler SMA Negeri 2 Kota Sukabumi. Bentuk penelelitian ini menggunakan kuantitatif dengan bentuk metode eksperimen dan pengambilan sampel dilakukan menggunakan total sampling dengan sampel penelitian berjumlah 23 orang pada peserta ektrakurikuler SMAN 2 Kota Sukabumi. Desain penelitian penelitian menggunakan One-Group Pretest-Posttest Design.Penelitian ini dilakukan untuk mengetahui baik atau tidaknya akurasi Shooting pada pemain futsal di ektrakurikuler SMA Negeri 2 Kota Sukabumi, instrumen penelitian berupa tes tendangan shooting ke sasaran. Penelitian dilakukan sebanyak 14 kali pertemuan dengan melakukan tes awal (pretest) kemudian diberikan perlakuan (treatment) 12 kali pertemuan dengan menggunakan permainan target lalu dilakukan tes akhir (posttest). Hasil uji nomalitas dengan Mean dari posttest 25,34 lebih besar dari pada pretest 18,86 dengan selisih Mean 6,4 maka terdapat perubahan setelah diberikan tereatment. Hasil pengujian hipotesis dengan menggunakan uji t, dapat diketahui nilai t hitung 17,450 lebih besar dari > t tabel 1,717. Dari hasil nilai uji t Sig yang diperoleh yaitu 0,000 lebih kecil < 0,05, maka $H o$ di tolak dan $\mathrm{Ha}$ diterima. Sehingga dapat disumpulkan adanya pengaruh yang signifikan dari model latihan permainan target terhadap akurasi shooting pada peserta ektrakurikuler SMA Negeri 2 Kota Sukabumi.
\end{abstract}

Kata Kunci: Permainan Target; Akurasi Shooting; Futsal.

\begin{abstract}
This study focuses to determine the effect of target games on shooting accuracy in futsal games at SMAN 2 extracurricular Sukabumi. This research method using quantitative with the form of experimental methods and sampling was carried out using total samples of 23 research people in the extracurricular participants SMAN 2 Sukabumi. Research design using One-Group Pretest-Posttest design. This research was conducted to find out whether or not the accuracy of shooting in futsal players at extracurricular SMAN 2 Sukabumi, research instruments in the form of shooting kick tests to the target. The research was conducted 14 times by pretesting and given treatment. Used 12 times for the target game meeting and conducted posttest. The result of nomality test on Mean from posttest 25.34 is greater than the pretest 18.86 in a difference of Mean 6.4 and there is a change after treatment. Hypothetical test results using $t$ test, can be known $t$ calculated value 17,450 greater than $>t$ table 1,717. From the results of the test value of T Sig obtained is $0.000<0.05$, accordingly Ho is rejected and Ha is accepted. In conclusion it can be collected a significant effect of the target games practice model on shooting accuracy in extracurricular participants at SMAN 2 Sukabumi.
\end{abstract}

Keywords: Target Game; Shooting Accuracy; Futsal.

Dipublikasikan Oleh :

UPT Publikasi dan Pengelolaan Jurnal

Universitas Islam Kalimantan Muhammad Arsyad Al-Banjari Banjarmasin 


\section{PENDAHULUAN}

Permainan futsal memberikan manfaat bagi ketahanan tubuh dikarenakan dalam bermain futsal hampir tidak ada yang diam seorang pemain akan berlari ke segala arah di lapangan menjadikan tensi yang tinggi dan harus memiliki ketahan tubuh yang sangat baik. Pemain harus punya kemampuan teknik dasar yang harus dikuasai sehingga nantinya dapat mendukung bermain futsal dengan baik secara individu maupun secara tim, melakukan shooting dengan akurasi yang baik bukan merupakan hal yang mudah. Pemain harus betul-betul meguasai akurasi shooting, banyak sekali pemain yang melakukan shooting menggunakan kaki bagian dalam karena lebih epektif menjadikan sebuah gol.

Menurut Justinus Lhaksana (dalam Ikhsan Gunawan 2014:20) "futsal merupakan permainan yang sangat cepat dan dinamis. Dilihat dari segi lapangan yang relatif kecil dan hampir tidak ada ruangan untuk membuat kesalahan" oleh karena itu pemain harus memiliki stamina yang baik dan memiliki tingkat akurasi shooting yang baik. Futsal merupakan salah satu permainan cabang olahraga yang menuntut kemampuan fisik yang tinggi dalam permainannya dengan gerakan-gerakan yang sangat kompleks saat dalam permainan futsal meurut Faiz Faozi (2019:184).

Seklolah dapat memilih untuk menetapkan kegiatan ektrakurikuler yang didasarkan pada bakat dan minat siswa seiring masuk nya futsal ke sekolah, di setiap sekolah pasti memiliki ektrakurikuler futsal dikarenakan futsal sangat diminati para siswa. Banyak sekali kegiatan pertandingan futsal antar sekolah di tingkat kota, kabupaten maupun tingkat yang lebih tinggi. Dengan adanya pertandingan tersebut akan menggali potensi yang dimiliki oleh siswa untuk membanggakan sekolah dengan cara menjadi juara di setiap pertandingan.

Pada perminan futsal seseorang sangat membutuhkan kemampuan dalam menguasai teknik dasar bermain futsal terutama teknik dasar shooting. Menurut Justinus Lhaksana (dalam Pamungkas 2013:22) "shooting merupakan teknik dasar yang harus dikuasai oleh setiap pemain, karena setiap pemain memiliki kesempatan untuk menciptakan gol ke gawang lawan". Pada teknik permainan futsal yang lebih dominan dilakukan yaitu passsing dan shooting. Dari kedua teknik yang dominan dilakukan shooting sangat penting karena dapat membuahkan hasil atau gol. Berdasarkan hasil observasi awal peneliti di ekstrakulikuler futsal SMAN 2 Kota Sukabumi terdapat permasalahan yaitu saat sedang melakukan shooting. Terlihat ketika pelatih memberikan games pada sesi saltihan, pemain masih sering melakukan tendangan shooting yang masih melebar atau melambung di atas mistar gawang. Hal ini yang membuat peneliti untuk meneliti permasalahan ini.

\section{METODE}

Menurut Sugiyono (2012:2) "dalam penelitian ada empat kata kunci yang perlu diperhatikan yaitu, cara ilmiah, data, tujuan, dan kegunaan. Cara ilmiah berarti kegiatan penelititan yang berdasarkan pada ciri keilmuan, yaitu rasional, empiris, dan sistematis". Adapun metode penelititan ini menggunakan metode kuantitatif dengan bentuk eksperimen. Menurut penjelasan Sugiyono (2012:72) "metode eksperimen yaitu metode yang menggunakan perlakuan atau (treatment) dengan metode ini dapat diartikan bahwa metode eksperimen digunakan untuk mencari pengaruh perlakuan tertentu terhadap yang lain dalam kondisi yang terkendalikan".

\section{HASIL DAN PEMBAHASAN}

\section{Tabel 1. Deskriprif Statistik penelitian}

\begin{tabular}{|l|r|c|r|r|}
\hline \multicolumn{7}{|c|}{ Statistik } \\
& \multicolumn{7}{c|}{ Akurasi Sooting } \\
\hline & N & Mean & Std. Deviation & Variance \\
\hline Hasil Pretest & 23 & 18.86 & 4.69 & 22.02 \\
\hline Hasil Posttest & 23 & 25.34 & 3.60 & 12.96 \\
\hline
\end{tabular}

Maka hasil tabel yang sudah tertera di atas terdapat Mean dari hasil pengujian hipotesis bahwa posttest 25,34 lebih besar dari pada pretest 18,86 dengan selisih Mean 6,4 maka terdapat perubahan setelah diberikan tereatment. Hasil pengujian hipotesis dengan menggunakan uji t, dapat diketahui nilai uji $\mathrm{t}$ Sig yang diperoleh yaitu 0,000 lebih kecil $<0,05$ dapat disimpulkan hipotesis yang berbunyi "Ada pengaruh permainan target terhadap akurasi shooting pada permainan futsal dalam ektrakurikuler SMAN 2 Kota Sukabumi" diterma.

Beberapa hal yang harus diperhatikan dalam melakukan shooting yaitu akurasi, jauhnya tendangan dan kerasnya tendangan, faktor yang dapat mendukung tiga hal tersebut yaitu latihan teknik dan adanya latihan shooting secara khusus. Metode permainan target merupakan bentuk latihan yang bertujuan mendorong para

\section{Dipublikasikan Oleh :}

UPT Publikasi dan Pengelolaan Jurnal

Universitas Islam Kalimantan Muhammad Arsyad Al-Banjari Banjarmasin 
pemain untuk mengembangkan kesadaran taktikal dan kemampuan pembuatan keputusan dalam melalukan shooting. Pemberian treatment latihan permainan target selama 12 kali pertemuan dengan 3 kali dalam seminggu bertujuan untuk mengetahui pengaruh dari latihan akurasi shooting pada ektrakurikuler SMAN 2 Kota Sukabumi.

\section{PENUTUP}

Berdasarkan hasil penelitian dapat disimpulkan adanya pengaruh yang signifikan dari motede latihan menggunakan permainan target untuk peningkatan akurasi shooting pada peserta ekstrakurikuler SMAN 2 Kota Sukabumi.. hasil Mean dari pretest 18,86 dan posttest 25,34 dengan selisih Mean 6,4 maka mengalami peningkatan. Terlihat dari hasil pengujian hipotesis dengan menggunakan uji t, dapat diketahui nilai Sig yang diperoleh yaitu 0,000 lebih kecil < dari 0,05 maka dengan demikian hasil dari penelitian yang bejudul pengaruh permainan target terhadap akurasi shooting pada permainan futsal dalam ektrakurikuler SMAN 2 Kota Sukabumi terdapat perngaruh yang signifikan.

Saran dari peneliti Berdasarkan hasil penelitian yang telah dilakukan peneliti, maka peneliti mempunyai implikasi untuk dijadikan pertimbangan yang baik :

1. Menjadikan bahan evaluasi bagi pelatih dalam melatih futsal khusunya pada kemampuan shooting. kemudian sebagai acuan dalam memberikan latihan yang lebih diperhatikan dalam teknik akurasi shooting yang dibutuhkan oleh pemain.

2. Bagi siswa yang mengikuti ektrakurikuler futsal, dengan adanya bentuk latihan permianan target ini dapat meningkatkan keterampilan shooting.

\section{REFERENSI}

Faozi, F. (2019). Pengaruh Penggunaan Aplikasi Nike Training Club Terhadap Peningkatan Vo2max Pada Pemain Ekstrakurikuler Futsal Putri Man 1 Kabupaten Sukabumi . Jurnal Ilmiah Fakultas Keguruan dan Ilmu Pendidikan , 184.

Gunawan, I. (2014). Tingkat Pengetahuan Siswa Tentang Taktik dan Strategi Bermain Futsal pada Siswa Peserta Ekstrakurikuler Futsal di SMA Muhammadiyah 1 Muntilan tahun 2014. Skripsi.

Hawindri, B. S. (2016). Pemanfaatan Panduan Latihan Teknik Dasar Futsal Bagi Atlet Pemula. Jurnal Prosiding Seminar Nasional Peran Pendidikan Jasmani Dalam Menyangga Interdisipliner Ilmu Keolahragaan.

Ibrahim, G. F. (2018). Pengembangan Model Latihan Shooting Futsal Melalui Media Aplikasi Berbasis Android pada Usia 14-18 Tahun. Skripsi.

Mubarok, f. (2017). Penerapan Media Audio Visual Terhadap Ketepatan Shooting Bola Pada Permainan Futsal. Jurnal Pendidikan Olahraga dan Kesehatan, 533.

Pamungkas, Y. D. (2013). tingkat keterampilan teknik dasar bermain futsal peserta ekstrakurikuler futsal SMA dan SMK Yayasan PIRI Daerah Istimewa Yogyakarta. Skipsi, 22.

Sugiyono, P. D. (2012). METODE PENELITIAN KUANTITATIF KUALITATIF DAN R\&D. Bandung: Alfabeta, cv. Jl. Gegerkalong Hilir no. 84 Bandung.

Wahidin. (2018). Pengaruh Latihan Permainan Target terhadap Ketepatan Shooting Menggunakan Kaki Bagian Dalam pada Peserta Ekstrakurikuler Futsal di SMP Negeri 4 Kota Sukabumi Tahun 2017. skripsi .

Dipublikasikan Oleh :

UPT Publikasi dan Pengelolaan Jurnal

Universitas Islam Kalimantan Muhammad Arsyad Al-Banjari Banjarmasin 